\title{
Comparative Effect of Soil and Foliar Application of Sulfur on Maize
}

\author{
Qamar Sarfaraz ${ }^{1}$, Sajida Perveen ${ }^{1}$, Qudratullah Shahab ${ }^{1}$, Dost Muhammad ${ }^{1}$, \\ Saqib Bashir ${ }^{2}$, Nazeer Ahmed ${ }^{3}$, Saeed Ahmed ${ }^{4}$, Muhammad Shahid-Ul-Islam ${ }^{5}$ \\ and Israr Asghar ${ }^{6}$ \\ ${ }^{1}$ Department of Soil and Environmental Sciences, The University of Agriculture Peshawar-Pakistan \\ ${ }^{2}$ Department of Agronomy, The University of Agriculture Peshawar-Pakistan. \\ ${ }^{3}$ Department of Entomology, The University of Agriculture Peshawar-Pakistan. \\ ${ }^{4}$ Department of Horticulture, The University of Agriculture Peshawar-Pakistan \\ ${ }^{5}$ Department of Food Science and Technology, The University of Agriculture Peshawar-Pakistan \\ Soil and Water Testing Laboratory, ${ }^{6}$ Department of Agriculture, Research Wing AJK \\ The University of Agriculture, Peshawar \\ Corresponding author: Qamar Sarfaraz(qamarsarfraz@yahoo.com)
}

\begin{abstract}
A field experiment was carried out to study the comparative effect of soil and foliar application of sulfur on maize at New Development Research Farm of The University of Agriculture Peshawar during 2012. The experiment was laid in randomized complete block design with three replications. For soil sulfur ammonium sulphate was applied at sowing @ 0, 20, 40,60, 80 and $100 \mathrm{~kg} \mathrm{ha}^{-1}$ while foliar sulfur was applied in two split doses @ 4, 8, 12, 16 and $20 \mathrm{~kg} \mathrm{ha}^{-1}$. Half dose at knee height and half at silking stage. Almost all the treatments have significantly affected all the agronomic and yield components of maize. Maximum grains yield $\left(4060 \mathrm{~kg} \mathrm{ha}^{-1}\right)$ was recorded in T6 and T11 i.e. $60 \mathrm{~kg} \mathrm{ha}^{-1}$ sulfur application in soil. Similarly biological yield $\left(12490 \mathrm{~kg} \mathrm{ha}^{-1}\right)$ and ear weight $\left(185.5 \mathrm{~g} \mathrm{ear}^{-1}\right)$ were also significant at $60 \mathrm{~kg} \mathrm{ha}^{-1}$. The maximum sulfate concentration in leaves was recorded in T6 (0.390\%) and T11 (0.370\%) receiving sulfur @ 100 and $20 \mathrm{~kg} \mathrm{ha}$ via soil and foliar application. Sulfur application had significant effect on nitrogen and phosphorus uptake. Up to $60 \mathrm{~kg} \mathrm{ha}^{-1}$ nitrogen was increased while above this become constant and finally declined and phosphorus up to $60 \mathrm{~kg} \mathrm{ha}^{-1}$ increased but decreased drastically above it. On potassium uptake S has no significant effect. At post harvest soil samples maximum $\mathrm{SO}_{4}^{-}-\mathrm{S}$ contents were found in soil where $\mathrm{S}$ was applied @ $100 \mathrm{~kg} \mathrm{ha}^{-1}$ and foliar application has little effect on soil sulfur. In foliar application maximum grains $\left(3237 \mathrm{~kg} \mathrm{ha}^{-1}\right)$ and biological yield (9340 $\mathrm{kg} \mathrm{ha}^{-1}$ ) was recorded in T11 which received S @ $20 \mathrm{~kg} \mathrm{ha}^{-1}$. Therefore it can be concluded that soil application of sulfur @ $60 \mathrm{~kg} \mathrm{ha}^{-1}$ at sowing time can be practiced to get substantial growth and yield of maize. In foliar application maximum grain and biological yield (3237 and $9340 \mathrm{~kg} \mathrm{ha}^{-1}$ ) was found in 111 respectively. Plant height, ear weight, ear length, 1000 grains weight were also maximum in 111 where sulfurwas applied @ $20 \mathrm{~kg} \mathrm{ha}$ by foliar application.
\end{abstract}

Keywords: maize, yield, sulfur, comparison, foliar, soil, spray

\section{Introduction:}

Among cereals, maize (Zea mays L.) ranks third in the world, second only to wheat and rice and is an important food and feed crop. It is known as a huge agricultural economic value crop, because of its long-term use in agricultural industry. Corn in Pakistan, grown on of approximately 1.05 million hectares, the total output of 3.6 million tons and average grain yield of $1880 \mathrm{~kg} \mathrm{ha}^{-1}$ is great far lower than other developing countries. This low productivity is due to a variety of reasons. Plant Nutrition mismanagement measurement is the main one. Accordingly, it is need to develop better this main component through technology to obtain high production and quality of corn [MINFAL, 2008-2009].

In crop production, sometimes sulfur is considered to be forgotten secondary nutrient. However it is most essential for activity of proteolytic enzymes and synthesis of amino acids. If adequate supply sulfur is ensured in the field it improves yield and quality of crops. The actual importance of sulfur has been noticed in the recent past due to exhaustive farming with high yielding varieties and the use of complex fertilizers, which led to sulfur deficiency in a lot of soils. In Tamil Nadu maize is one of the important commercial crops used as a constituent in poultry and cattle fee-d. Maize crop responds well to sulfur fertilization and it removes about 30$70 \mathrm{~kg} \mathrm{~S} \mathrm{ha}^{-1}$. Several workers have reported that uptake of major nutrients is also positively influenced by sulfur (Bharathi and Poongothai, 2008).

About $98 \%$ of total soil sulfur may be found in organic forms and is related with a diverse mixture of plant, animal residues and soil micro-organisms (Bloem, 1998). With depth the organic sulfur concentration is 
usually on the pattern of organic matter concentration in soils (Probert, 1980). Soil organic sulfur is separated in two main groups: i.e, sulfur atoms with reduced and oxidized states. About 1 to $3 \%$ of the soil organic sulfur can be assumed the part of microbiological biomass (Stevenson, 1986), while from present study of Banerjee et al. (1993) soil microbial biomass sulfur is generally $1.5-5 \%$ of total soil organic sulfur. In microbial cells amino acids and proteins are the most important type of sulfur (Banerjee and Chapman, 1996).

Inorganic sulfur is generally greatly in fewer amounts in most of the agricultural soils than organic sulfur (Bohn $e t$ a/., 1986). The mainly ordinary appearance of inorganic sulfur is sulfate and may be subdivided into mineral sulfur, $\mathrm{SO}_{4}{ }^{2-}$ in soil and adsorbed $\mathrm{SO}_{4}{ }^{2-}$ (Barber, 1995). Sulfur possibly precipitates with calcium, magnesium or sodium to form their sulfates. Great quantities of sulphide metals like pyrite accumulated in tidal marshlands. Once draining these areas, the sulfur holding complexes are oxidized to $\mathrm{SO}_{4}{ }_{4}^{2-}$ attended by a drop off in $\mathrm{pH}$. If adsorbed $\mathrm{SO}_{4}{ }^{2-}$ is not willingly available to crop, every management causing a decline in retention and a resultant addition of $\mathrm{SO}_{4}{ }^{2-}$ in soil solution must increase $\mathrm{SO}_{4}{ }^{2-}$ availability to plants (Elkins and Ensminger. 1971).

Mehlich (1964) originated that discharge of adsorbed $\mathrm{SO}_{4}{ }^{2-}$ was related to the count of succeeding rise of $\mathrm{Ca}(\mathrm{OH})_{2}$, that is believed the effect of increased $\mathrm{pH}$. Therefore, small $\mathrm{SO}_{4}{ }^{2-}$ adsorption is probable in upper soils which are sufficiently limed (Evans, 1986) and thus the combined application of limestone and gypsum consequences in an improved availability of $\mathrm{SO}_{4}{ }^{2-}$ (Serrano et al, 1999).

Keeping in view the importance of sulfur in the production of maize, current work was designed to assess the possibility of sustaining high crop yield through the application of soil and foliar sulfur with these objectives: To study the effect of sulfur on NPK uptake by maize. To find out effect of sulfur on yield and yield components of maize.

\section{Materials and Methods:}

The research project "comparative effect of soil and foliar application of sulfur on maize" was conducted at New Developmental Farm (NDF) of The University of Agriculture, Peshawar during June, 2012. The experiment was carried out in Randomized Complete Block Design and replicated three times. Ammonium sulfate $\left[\left(\mathrm{NH}_{4}\right)_{2} \mathrm{SO}_{4}\right]$ was used to apply sulfur. The plot size was $3 \mathrm{~m}$ x $5 \mathrm{~m}$ and Azam variety of maize was sown. A basal dose 120, 90 and $60 \mathrm{~kg} \mathrm{ha}^{-1}$ nitrogen, $\mathrm{P}_{2} \mathrm{O}_{5}$ and $\mathrm{K}_{2} \mathrm{O}$ was applied to all plots respectively. All other cultural practices including hoeing, weeding, and irrigation were carried out to all plots uniformly. A composite soil sample was taken for physic-chemical properties, shown in Table 1.

Table 1.Physico-chemical properties of experimental site

\begin{tabular}{|l|c|c|}
\hline \multicolumn{1}{|c|}{ Soil Properties } & Unit & Value \\
\hline Sand & $\%$ & 16.00 \\
\hline Silt & $\%$ & 52.40 \\
\hline Clay & $\%$ & 31.60 \\
\hline Soil Texture & -- & Silty Clay Loam \\
\hline $\mathrm{pH}_{(1: 5)}$ & -- & 0.42 \\
\hline $\mathrm{EC}_{(1: 5)}$ & $\mathrm{dS} \mathrm{m}^{-1}$ & 0.16 \\
\hline Organic Matter & $\%$ & 0.84 \\
\hline Total Nitrogen & $\%$ & 0.09 \\
\hline AB-DTPA extractable P & $\mathrm{mg} \mathrm{kg}^{-1}$ & 3.20 \\
\hline AB-DTPA extractable K & $\mathrm{mg} \mathrm{kg}^{-1}$ & 103 \\
\hline Available Sulfate S & $\mathrm{mg} \mathrm{kg}^{-1}$ & 18.62 \\
\hline
\end{tabular}

Soil application of was done at sowing time while foliar application of sulfur was applied in two split doses; half dose was applied at knee height stage and remaining half at silking stage. The application of sulfur levels to each treatment was mixed with small amount of detergents in water and was applied to each experimental unit with the help of spraying machine. Following treatment combinations soil and foliar T1 $(0 \mathrm{~kg}$ $\left.\mathrm{ha}^{-1}\right)$, T2 $\left(20 \mathrm{~kg} \mathrm{ha}^{-1}\right)$, T3 $\left(40 \mathrm{~kg} \mathrm{ha}^{-1}\right)$, T4 $\left(60 \mathrm{~kg} \mathrm{ha}^{-1}\right)$, T5 $\left(80 \mathrm{~kg} \mathrm{ha}^{-1}\right), \mathrm{T} 6\left(100 \mathrm{~kg} \mathrm{ha}^{-1}\right)$ and T7 $\left(4 \mathrm{~kg} \mathrm{ha}^{-1}\right), \mathrm{T} 8(8$ $\left.\mathrm{kg} \mathrm{ha}^{-1}\right), \mathrm{T} 9\left(9 \mathrm{~kg} \mathrm{ha}^{-1}\right), \mathrm{T} 10\left(16 \mathrm{~kg} \mathrm{ha}^{-1}\right), \mathrm{T} 11\left(20 \mathrm{~kg} \mathrm{ha}^{-1}\right)$ were applied respectively to maize.

\section{Biological Yield}

\section{Results and discussion:}

The results of biological yield are given in Table 2. The results showed that there were significant differences among all treatments. Maximum biological yield $12490 \mathrm{~kg} \mathrm{ha}^{-1}$ was recorded in treatment where 60 $\mathrm{kg} \mathrm{ha}^{-1}$ was applied in soil. The lowest biological yield $7470 \mathrm{~kg} \mathrm{ha}^{-1}$ was observed in control which received no sulfur. Biological yield above $60 \mathrm{~kg} \mathrm{ha}^{-1}$ was lower which shows antagonistic effects of $\mathrm{S}$ beyond $60 \mathrm{~kg} \mathrm{ha}^{-1}$ application. This may be trait to lower $\mathrm{pH}$ in treatments, which helped in bio transformation of insoluble $\mathrm{P}$ to available. In comparing the foliar application highest biological yield was noted in $\mathrm{T}_{11}$ which was significantly at par with $\mathrm{T} 8$. 
Table 1.Biological, grain yield, ear weight and 1000 grains weight as affected by different levels of soil and foliar application of sulfur

\begin{tabular}{|c|c|c|c|c|}
\hline \multirow{2}{*}{$\begin{array}{c}\text { Treatment } \\
\left(\mathrm{kgha}^{-1}\right)\end{array}$} & Biological Yield & Grain Yield & Ear weight & 1000 Grain weight \\
\hline & \multicolumn{2}{|c|}{$\mathbf{k g ~ h a}^{-1}$} & \multicolumn{2}{|c|}{$\mathbf{G}$} \\
\hline \multicolumn{5}{|c|}{ Soil } \\
\hline $\mathrm{T}_{1}$ Control & $7470 \mathrm{f}$ & $1952 \mathrm{~h}$ & $136.0 \mathrm{f}$ & $212.3 \mathrm{~h}$ \\
\hline $\mathrm{T}_{2} 20$ & 8770 de & $2685 \mathrm{f}$ & $155.1 \mathrm{~d}$ & 261.7 ef \\
\hline $\mathrm{T}_{3} 40$ & $10150 \mathrm{~b}$ & $3668 \mathrm{~b}$ & $164.1 \mathrm{c}$ & $277.7 \mathrm{~b}$ \\
\hline $\mathrm{T}_{4} 60$ & $12490 \mathrm{a}$ & $4060 \mathrm{a}$ & $185.2 \mathrm{a}$ & $300.7 \mathrm{a}$ \\
\hline $\mathrm{T}_{5} 80$ & $10650 \mathrm{~b}$ & $3938 \mathrm{a}$ & $173.0 \mathrm{~b}$ & $294.0 \mathrm{a}$ \\
\hline $\mathrm{T}_{6} 100$ & $9950 \mathrm{bc}$ & $3145 \mathrm{~cd}$ & $170.0 \mathrm{~b}$ & $264.3 \mathrm{c}$ \\
\hline \multicolumn{5}{|c|}{ Foliar } \\
\hline $\mathrm{T}_{7} 4$ & $8250 \mathrm{e}$ & $2373 \mathrm{~g}$ & $146.0 \mathrm{e}$ & $244.0 \mathrm{e}$ \\
\hline $\mathrm{T}_{8} 8$ & $8640 \mathrm{de}$ & $2859 \mathrm{e}$ & $160.0 \mathrm{c}$ & $254.0 \mathrm{~d}$ \\
\hline $\mathrm{T}_{9} 12$ & $8570 \mathrm{e}$ & $2874 \mathrm{e}$ & $161.0 \mathrm{c}$ & $268.7 \mathrm{c}$ \\
\hline $\mathrm{T}_{10} 16$ & 8570 e & $3007 \mathrm{de}$ & $162.3 \mathrm{c}$ & $277.7 \mathrm{~b}$ \\
\hline $\mathrm{T}_{11} 20$ & $9340 \mathrm{~cd}$ & $3237 \mathrm{c}$ & $163.0 \mathrm{c}$ & $280.7 \mathrm{~b}$ \\
\hline $\mathrm{CV} \%$ & 8.66 & 5.81 & 3.11 & 3.48 \\
\hline LSD value & 720.7 & 158.7 & 4.472 & 8.25 \\
\hline
\end{tabular}

In discussing the foliar application highest biological yield $\left(9340 \mathrm{~kg} \mathrm{ha}^{-1}\right)$ was noted in T11 which received sulfur@20 kg ha $\mathrm{kg}^{-1}$. These results were similar to rerults of Hussain and Khan, (2003), Germaani et al. (2006) and Imran et al. (2007). The results were dissimilar to findings of Haqani et al. (1989) according to him peak production of maize was obtained by $72 \mathrm{~kg} \mathrm{ha}^{-1} \mathrm{~S}$ fertilization. Similar results are shown by Baktash (2000).

\section{Grain Yield}

Results of grain yield as affected by different concentrations of $\mathrm{S}$ are presented in Table 2 . It can be seen from table that highest grain yield of $4060 \mathrm{~kg} \mathrm{ha}^{-1}$ was obtained from T4 where S was applied @ $60 \mathrm{~kg} \mathrm{ha}{ }^{-1}$ in soil followed by $3938 \mathrm{~kg} \mathrm{ha}^{-1}$ from T5 where $80 \mathrm{~kg} \mathrm{ha}^{-1} \mathrm{~S}$ was applied along with 120,90 and $60 \mathrm{~kg} \mathrm{ha}^{-1} \mathrm{~N}$, $\mathrm{P}_{2} \mathrm{O}_{5}$ and $\mathrm{K}_{2} \mathrm{O}$ respectively. Higher levels beyond $60 \mathrm{~kg} \mathrm{ha}^{-1}$ might have toxicity of $\mathrm{S}$ which may cause deficiency of other nutrients (P, K, Mo, and $\mathrm{Zn}$ ). The lowest grain yield was obtained from treatment $\mathrm{T} 1 \mathrm{which}$ was control $\left(0 \mathrm{~kg} \mathrm{ha}^{-1} \mathrm{~S}\right)$. In foliar application of sulfur maximum grain yield was attained $3237 \mathrm{~kg} \mathrm{ha}^{-1}$ in $\mathrm{T} 11$ when $20 \mathrm{~kg} \mathrm{ha}^{-1}$ sulfur was applied. Although over all grain yield of maize was lower compared to potential yield of maize but treatment T4 indicated that $S @ 60 \mathrm{~kg} \mathrm{ha}^{-1}$ was beneficial and S application beyond $60 \mathrm{~kg}$ ha ${ }^{1}$ may not be helpful for increasing yield of maize. Sulfur application along with nitrogen is the evidence by higher NUE. Sulfur effects on grain yield were more relevant showing the positive interaction. Gupta et al. (1997) accounted maximum yield with $60 \mathrm{~kg} \mathrm{ha}^{-1} \mathrm{~S}$ application while $72 \mathrm{~kg} \mathrm{ha}^{-1}$ was reported by Haq et al. (1980). Khan et al. (2006) reported $43 \%$ increase in grain yield when $60 \mathrm{~kg} \mathrm{ha}^{-1} \mathrm{~S}$ was applied. Results are disagreed to the results of Sakal et al. (2000) who detected $0.99 \mathrm{t} \mathrm{ha}^{-1}$ increase in grain yield when $40 \mathrm{~kg} \mathrm{ha}^{-1} \mathrm{~S}$ was applied.

\section{Ear Weight}

Results regarding to ear weight is shown in Table 2. It showed the significant difference among all treatments. Similar to other yield parameters, highest ear weight was recorded in T4 (185.2 g) when $60 \mathrm{~kg} \mathrm{ha}^{-1}$ sulfur was applied to soil followed by 173 and $170.0 \mathrm{~g}$ produced with fertilization with 80 and $100 \mathrm{~kg} \mathrm{ha}^{-1} \mathrm{~S}$. Treatments T8, T9, T10 and T11 had no significant difference among their means and were not statistically comparable. The results are in confirmation with results of Mishra (1996) and Baktash (2000).

\section{Thousand grain weight}

The results on 1000 grains weight showed that maximum 1000 grains weight has been obtained in T4 which is at par with T5 where S was applied @60 and $80 \mathrm{~kg} \mathrm{ha}^{-1}$ respectively. In case of foliar application highest 1000 grains weight was recorded in T11 which was not significantly different from T10 It is clear from the data that $60 \mathrm{~kg} \mathrm{ha}^{-1}$ soil and $16 \mathrm{~kg} \mathrm{ha}^{-1}$ foliar application gave maximum 1000 grains weight. 


\section{Sulfate sulfur concentration in leaves}

The results on $\mathrm{SO}_{4}$-S concentration in leaves are shown in Table 3. It showed the significant difference among treatments. Maximum concentration of $\mathrm{SO}_{4}-\mathrm{S}(0.390 \%)$ was recorded treatment where $100 \mathrm{~kg} \mathrm{ha}^{-1}$ sulfur was applied by soil application while minimum $(0.090 \%)$ was recorded in control plot. In comparing foliar applications of sulfur maximum concentration $(0.370 \%)$ was calculated in $\mathrm{t}_{11}$ which was non-significant with T8. It was found by Mahapatra et al. (2000) that total sulfur uptake increased by increasing sulfur rate.

Table 2. $\mathrm{SO}_{4}-\mathrm{S}$ concentration in leaves, $\mathrm{SO}_{4}$-S uptake, and $\mathrm{NPK}$ uptake as affected by different levels of soil and foliar application of sulfur

\begin{tabular}{|c|c|c|c|c|c|}
\hline \multirow[t]{2}{*}{$\underset{\left(\text { kgha }^{-1}\right)}{\text { Treatment }}$} & S Conc. in leaves & S uptake & N uptake & $\begin{array}{c}\mathbf{P} \\
\text { uptake }\end{array}$ & K uptake \\
\hline & $\%$ & \multicolumn{4}{|c|}{$\mathrm{kg} \mathrm{ha}^{-1}$} \\
\hline \multicolumn{6}{|c|}{ Soil } \\
\hline $\mathrm{T}_{1}$ Control & $0.090 \mathrm{~h}$ & $6.80 \mathrm{~g}$ & $32.02 \mathrm{e}$ & $13.07 \mathrm{e}$ & 75.27 \\
\hline $\mathrm{T}_{2} 20$ & $0.120 \mathrm{~g}$ & $10.11 \mathrm{f}$ & $39.47 \mathrm{~cd}$ & $19.87 \mathrm{c}$ & 93.60 \\
\hline $\mathrm{T}_{3} 40$ & $0.230 \mathrm{~d}$ & $23.54 \mathrm{~d}$ & $46.57 \mathrm{bc}$ & $23.40 \mathrm{~b}$ & 107.90 \\
\hline $\mathrm{T}_{4} 60$ & $0.270 \mathrm{c}$ & $34.16 \mathrm{~b}$ & $73.02 \mathrm{a}$ & $31.26 \mathrm{a}$ & 125.53 \\
\hline $\mathrm{T}_{5} 80$ & $0.330 \mathrm{~b}$ & $34.77 \mathrm{~b}$ & $50.12 \mathrm{~b}$ & $24.50 \mathrm{~b}$ & 109.33 \\
\hline $\mathrm{T}_{6} 100$ & $0.390 \mathrm{a}$ & $39.23 \mathrm{a}$ & $43.04 \mathrm{bcd}$ & $20.70 \mathrm{c}$ & 104.83 \\
\hline \multicolumn{6}{|c|}{ Foliar } \\
\hline $\mathrm{T}_{7} 4$ & $0.150 \mathrm{f}$ & $12.05 \mathrm{f}$ & $36.99 \mathrm{de}$ & $16.40 \mathrm{~d}$ & 87.23 \\
\hline $\mathrm{T}_{8} 8$ & $0.180 \mathrm{e}$ & $15.85 \mathrm{e}$ & $39.77 \mathrm{~cd}$ & $16.80 \mathrm{~d}$ & 92.17 \\
\hline $\mathrm{T}_{9} 12$ & $0.270 \mathrm{c}$ & $22.73 \mathrm{~d}$ & $39.82 \mathrm{~cd}$ & $16.73 \mathrm{~d}$ & 92.00 \\
\hline $\mathrm{T}_{10} 16$ & $0.320 \mathrm{~b}$ & $27.73 \mathrm{c}$ & $40.44 \mathrm{~cd}$ & $17.43 \mathrm{~d}$ & 91.83 \\
\hline $\mathrm{T}_{11} 20$ & $0.370 \mathrm{ab}$ & $34.54 \mathrm{~b}$ & $44.75 \mathrm{bc}$ & $20.30 \mathrm{c}$ & 99.53 \\
\hline $\mathrm{CV} \%$ & 11.46 & 14.37 & 18.80 & 13.41 & 16.15 \\
\hline LSD value & 0.028 & 3.033 & 7.418 & 2.39 & $\mathrm{~ns}$ \\
\hline
\end{tabular}

\section{Sulfate sulfur uptake by Maize}

Data on sulfur uptake is shown in Table 3. It is clear from table that Sulfur uptake was significantly affected by different levels of sulfur application. Maximum uptake $\left(39.23 \mathrm{~kg} \mathrm{ha}^{-1}\right)$ of sulfur was noted in T6 where sulfur was applied in soil and minimum uptake was recorded in control plot. Treatments T4, T5 and T11 have same results at $5 \%$ level of significance. Vijender et al. (1995) reported that plant sulfur uptake increased with 60 and $30 \mathrm{mg} \mathrm{kg}^{-1}$ in $\mathrm{S}$ deficient and medium S soils.

\section{Nitrogen uptake}

Results in Table 3. showed that $\mathrm{N}$ uptake by maize crop is significantly affected by sulfur application by different methods. From the data it is clear that maximum $\mathrm{N}$ uptake $\left(73.02 \mathrm{~kg} \mathrm{ha}^{-1}\right)$ was resulted from the treatment where $60 \mathrm{~kg} \mathrm{ha}^{-1}$ sulfur was applied by soil application followed by T3 and T5 where sulfur was applied @ 40 and $80 \mathrm{~kg} \mathrm{ha}^{-1}$ respectively while lowest uptake $\left(32.02 \mathrm{~kg} \mathrm{ha}^{-1}\right)$ was calculated in control plot where sulfur was neither applied by soil nor foliar application. In comparing $\mathrm{N}$ uptake affected by soil and foliar application $\mathrm{N}$ was most affected by soil application instead of foliar application. All the foliar applications of sulfur have same results at $5 \%$ level of significance showing non significant behavior on $\mathrm{N}$ uptake by maize crop in prevailing conditions. Taalab et aL (2008) revealed that combination of various phosphorus sources with sulfur resulted in better effect on N, P and K uptake by com than phosphorus sources alone. Fismes et al. (2000) stated that sulfur addition improves the $\mathrm{N}$ use efficiency and significantly affects the $\mathrm{N}$ uptake when applied @ $75 \mathrm{~kg} \mathrm{ha}^{-1}$ to oilseed rape.

\section{Phosphorus uptake}

The results of sulfur application at different levels by different methods on $\mathrm{P}$ uptake are shown in Table 3. From the table it can be stated that $P$ uptake was significantly affected by sulfur application. Maximum $P$ uptake (31.26 kg ha ${ }^{-1}$ ) was noted in T4 where S was applied @ $60 \mathrm{~kg} \mathrm{ha}^{-1}$ by soil application followed by T3 and T5 receiving 40 and $80 \mathrm{~kg} \mathrm{ha}^{-1}$ sulfur. Minimum P uptake $\left(13.07 \mathrm{~kg} \mathrm{ha}^{-1}\right.$ ) was recorded in control plot (no sulfur). Treatments T2, T6 and T11 have same effects on P uptake which received 20, 100 and $20 \mathrm{~kg} \mathrm{ha}^{-1}$ by soil and foliar application respectively. In foliar application P uptake was not significantly affected by applying sulfur to plants except T11 which received S @ $20 \mathrm{~kg} \mathrm{ha}^{-1}$ by foliar spray in two splits. Shamima and Haq 
(2002) recorded increase in $\mathrm{P}$ concentration in plant tissues when sulfur was applied at rate of $60 \mathrm{~kg} \mathrm{ha}^{-1}$ while sulfur beyond $60 \mathrm{~kg} \mathrm{ha}^{-1} \mathrm{P}$ uptake is antagonistically affected. In another study Aulakh et al. (1990) noted that phosphorus with sulfur was harmful when maximum dose of sulfur was applied that may have prevented $\mathrm{P}$ uptake in plant and in soil its concentration is enhanced.

\section{Potassium uptake}

The data on $\mathrm{K}$ uptake as affected by sulfur application at different doses and by methods are shown in Table 3. which showed that sulfur application has no significant difference on uptake of K by maize. Maximum $\mathrm{K}$ uptake $\left(125.53 \mathrm{~kg} \mathrm{ha}^{-1}\right)$ was noted in treatment $\mathrm{T} 4$ where sulfur was applied at rate of $60 \mathrm{~kg} \mathrm{ha}^{-1}$ while minimum was recorded in control plot $\left(75.27 \mathrm{~kg} \mathrm{ha}^{-1}\right)$. From the data it is shown that in soil application with increasing levels of sulfur K also increased but not enough increase that can be differentiated @ $5 \%$ level of significance. Singh, (1970) revealed this effect might be qualified to acidity caused by sulfur application, resulted in mobilization of nutrient inside the plant. Results in table 6. show that by foliar application of sulfur there is no major effect on $\mathrm{K}$ uptake.

\section{Conclusion and Recommendations:}

Maximum yield of maize was achieved @ $60 \mathrm{~kg} \mathrm{ha}^{-1}$ sulfur application in soil and it decreased beyond $60 \mathrm{~kg} \mathrm{ha}^{-1}$. This is optimal level of sulfur application in soil and above this level of sulfur yield and yield components are lowered causing toxicity. Maximum $\mathrm{N}$ and $\mathrm{P}$ uptake were recorded when sulfur was applied at $60 \mathrm{~kg} \mathrm{ha}^{-1}$, after this limit $\mathrm{N}$ uptake did not affect by $\mathrm{S}$ application and $\mathrm{P}$ uptake decreased when $\mathrm{S}$ exceed $60 \mathrm{~kg}$ $\mathrm{ha}^{-1}$. K uptake was not significantly affected by $\mathrm{S}$ application by soil and foliar application. Addition of $\mathrm{S}$ fertilizer (Ammonium Sulfate) resulted in build up $\mathrm{SO}_{4}-\mathrm{S}$ level of soil while foliar application has minor effect on soil sulfur. Highest $\mathrm{SO}_{4}-\mathrm{S}$ was calculated in leaves when $\mathrm{S}$ was applied in soil @ $60 \mathrm{~kg} \mathrm{ha}^{-1}$ and $20 \mathrm{~kg} \mathrm{ha}^{-1}$ by foliar application.

Based on findings of present study following recommendation are suggested

To get maximum yield of maize $60 \mathrm{~kg} \mathrm{ha}^{-1}$ sulfur should be added to sulfur deficit soils along with NPK fertilizers. Foliar application of sulfur may attain yield comparable with soil application if it should applied in three or four splits instead of two. The experiment may be repeated to confirm these results of soil Vs foliar application of sulfur on maize.

\section{References}

[1]. Aulakh, A. S., N. S. Pasricha and A. S. Azad. 1990. P and S relationship for soybean on P and S deficient soil. Soil Science. 4(150):705-709.

[2]. Baktash, F. Y. 2000. Response of maize to different levels of sulfur fertilizer. Bulletin of Faculty of Agriculture. University of Cairo. 51(2):123-137.

[3]. Banerjee, M. R. and S. J. Chapman. 1996. The significance of microbial biomass sulfur in soil. Biological Fertile Soils. 22: 116123 .

[4]. Banerjee, M. R., S. J. Chapman and K. Killham. 1993. Factors influencing the determination of microbial biomass sulfur in soil. Common Soil Science and Plant Analysis. 24: 939-950.

[5]. Barber, S. A. 1995. Soil Nutrient Bioavailability. John Wiley \& Sons, New York

[6]. Bharathi, C. and S. Poongothai. 2008. Direct and Residual Effect of Sulfur on Growth, Nutrient Uptake, Yield and its Use Efficiency in Maize and Subsequent Greengram. Research Journal of Agriculture and Biological Science. 4(5): $368-372$.

[7]. Bloem, E. M. and S. B. Von. 1998. Agrarokosystemen unter besonderer Beruksichtigung hydrologischer and bodenphysikalischer Standorteigenschaften. Vol. 192, p-156.

[8]. Bohn, H. L., N. J. Barrow, S. S. Rajan and R. L. Parfitt. 1986. Reactions of inorganic sulfur in soils. In:Tabatabai, MA. (Ed.). Sulfur in Agriculture, Agron. Monogr, vol.27. ASA, CSSA, and ISSSA, Madison, WI, p.233-249.

[9]. Elkins, D. M. and L. E. Ensminger. 1971. Effect of soil pH on the availability of adsorbed sulfate. Soil Science Society of American Procduction. 35: 931-943.

[10]. Eriksen, J. 1996. Incorporation of S into soil organic matter in the field as determined by the natural abundance of stable isotopes. Bio. Fertil. Soils 22: 149-155.

[11]. Evans, A. J. 1986. Effects of dissolved organic carbon and sulfate on aluminum mobilization in forest soil columns. Soil Science Society of America Journal. 50: 1576-1578.

[12]. Ghani, A., R. G. McLaren and R. S. Swift. 1990. Seasonal fluctuations of sulfate and soil microbial biomass-S in the surface of a Wakanui soil. New Zealand soils. Biologically Fertile Soils. 11:68-71.

[13]. Gupta, J. P., V. K. Jalali, W. Pardeep, and P. Wall. 1997. Effect of sulfur sources and levels on yield and sulfur uptake in rice. International Journal of Tropical Agriculture. 15:177-179.

[14]. Gupta, V. V. S. R. and J. J. Germida. 1989. Microbial biomass and extractable sulfate sulfite levels in native and cultivated soils as influenced by air-drying and rewettin. Canadian Journal of Soil Science. 69: 889-894.

[15]. Haq, I. U., D. Zuhar and N. Z. Hussain. 1989. Effect of sulfur fertilization on yield of maize. Sarhad Journal of Agriculture 5(3):56-63.

[16]. Hussain, A. and S. Khan. 2003. Fodder yield and quality of summer cereal fodder crops/hybrid under various regimes. International Journal of Science, Technology and Development. 22:41-45.

[17]. Imran, M., A. Bakhash, S. Khan, A. Hussain, Z. A. Gurmani and M. Qasim. 2007. Forrage Yield and quality potential of dual-type pearl millet varieties under rain fed conditions of NARC. Pakistan Journal of Agriculture Research. 20(3-4):137-142.

[18]. Khan, M. J., M. H. khan and R. A. Khattak. 2006. Response of maize to different levels of sulfur. Communications in Soil Science and Plant Analysis. 37:41-51. 
[19]. Mahapatra, S. S., G. H. Santra and K. N. Tiwair. 2000. Response of wheat to souces and graded doses of sulfur as revealed by biomass yield and sulfur uptake by crops. Environment and Ecology. 18: 726-728.

[20]. Mehlich, A. 1964. Muence of sorbed hydroxyl and sulfate on liming efficiency, pH and conductivity. Soil Science Society American Proc. 28: 496-499.

[21]. MINFAL. 2008-09. Agriculture statistics of Pakistan. Govt, of Pakistan. Ministry of Food, Agriculture and Livestock, division (Economic wing) Islamabad.

[22]. Mishra, C. M. 1996. Response of sulfur on yield of groundnut under dry land conditions. Journal of Agriculture Madras. 83:469470.

[23]. National Atmospheric Deposition Program. (NADP) 2002. National atmospheric deposition program 2001 annual summary. NADP data report 2002-01. Illinois State Water Survey, Champaign, IL.

[24]. Probert, M. E. 1980. Sulfur in Australia, In: Freney JR, Nicholson AJ (eds), Australian Academy of Science Canberra. p. 158-169.

[25]. Sakal, R., A. P. Singh, R. B. Sinha amd M. Ismail. 2000. Relative performance of some sulfur sources on sulfur nutrition of crops in calcareous soils. Analysis of Agriculture Research. 21:206-211.

[26]. Serrano, R. E., J. S. Arias and P. G. Fernandez. 1999. Soil properties that affect sulfate adsorption by palexerults in western and central Spain. Community of Soil Science and Plant Analysis. 30: 1521-1530.

[27]. Singh, H. G. 1990. Effect of sulfur in preventing the occurrence of chlorosis peas. Agronomy Journal. 62:708

[28]. Stevenson, F. J. 1986. Cycles of soil: Carbon, Nitrogen, Phosphorus, Sulfur, Micronutrients. John Wiley \& Sons, New York.

[29]. Vijender, S., K. Vinod, S. P. S. Karwasra, V: Singh and V. Kumar. 1995. Interaction on S and Zn on dry matter yield concentration and uptake of $S$ in green gram. Crop Research Hisar. 9:32-41. 